\title{
Sedation with propofol controlled by endoscopists during percutaneous endoscopic gastrostomy
}

\author{
C. García-Suárez, L. López-Rosés, P. Olivencia, A. Lancho, A. González-Ramírez, E. Santos, \\ D. Carral, E. Castro and S. Ávila
}

Department of Gastroenterology. Hospital Xeral-Calde. Lugo, Spain

\begin{abstract}
Background: propofol is a hypnotic used with increasing frequency for sedation during endoscopic procedures. Most of the reports published related with its employment by non-anaesthesiologists, refers to basic endoscopy, with little reference to its use in advanced endoscopy.

Objective: to evaluate the efficacy and safety of propofol sedation administered by endoscopists, while performing percutaneous endoscopic gastrostomy, an advanced technique that is usually performed in high anesthetic level risk patients.

Material and methods: prospective study of a series of endoscopic gastrostomy performed consecutively in our department; the sedation was carried out exclusively with propofol. The staff in the room consisted of two medical gastroenterologists, a nurse and a nursing assistant. Propofol was administered by bolus doses adjusted to patient weight. Arterial oxygen saturation, heart rate and blood pressure were monitored; respiratory activity was monitored visually by observing respiratory excursions of the patient.

Results: we included 47 patients, with an average age of 82 years. $87 \%$ were ASA III and the rest, ASA IV. The mean dose of propofol was $51 \mathrm{mgr}$. Complications were recorded: 8 cases of desaturation and two of hypotension, all of them minor and quickly reversible. All procedures were carried out successfully, at a median time of 8 minutes.

Conclusion: the propofol sedation carried out by non-anaesthesiologist trained staff, seems to appear as a safe and effective procedure while performing percutaneous endoscopic gastrostomy.
\end{abstract}

Key words: Propofol. Percutaneous endoscopic gastrostomy. Sedation by non-anaesthesiologists.

Received: 27-10-09.

Accepted: 29-10-09.

Correspondence: Leopoldo López Rosés. Ronda de la República Argentina, 11.27002 Lugo.e-mail: leolopezroses@ hotmail.com
García-Suárez C, López-Rosés L, Olivencia P, Lancho A, González-Ramírez A, Santos E, Carral D, Castro E, Ávila S. Sedation with propofol controlled by endoscopists during percutaneous endoscopic gastrostomy. Rev Esp Enferm Dig 2010; 102: 249-256.

\section{INTRODUCTION}

The performance of endoscopic procedures under sedation and analgesia has become increasingly common in clinical practice, due on the one hand to the greater complexity and length of some of them and on the other partly because of the demand from patients to not be subjected to uncomfortable or painful examinations. Usually in endoscopic procedures, conscious sedation was used which was carried out with the use of benzodiazepines alone or in association with opioids. But in recent years, and in view of the good results published in medical literature, the number of endoscopists who have begun using more powerful hypnotic drugs, particularly propofol while practicing deeper levels of sedation (1-3), has increased. This has generated much controversy over who should be responsible for the sedation and monitoring of patients and whether non anesthesiologists are prepared or not to use propofol, mainly due to the narrow therapeutic index of this drug. The debate has been partially solved with the emergence of several clinical management guidelines published by various scientific societies, which set conditions to be fulfilled by staff dedicated to both conscious and deep sedation, and situations in which it must be carried out by anesthesiologists (4-12). However, despite the great number of published studies about sedation controlled by physicians or certified nurses, in gastrointestinal endoscopy (13-15), there are very few of them that value its use in advanced endoscopic procedures $(2,16-20)$. That is why we decided to prospectively 
evaluate the safety and quality of sedation with propofol controlled by endoscopists during the practice of percutaneous endoscopic gastrostomy, a procedure of some technical complexity and usually indicated in patients with anesthetic high risk, both of which put the procedure in the proximity of the generally accepted threshold necessary to consider the presence of an anesthesiologist.

\section{MATERIALS AND METHODS}

A prospective descriptive study was conducted that included all patients referred to the Endoscopy Unit of our department for the placement of a gastrostomy tube, from March to October 2008.

The procedure was performed in all cases using the pull technique and propofol was the only drug used for sedation.

Allergy to propofol, egg or soy, decompensated lung or heart disease, a history of anesthetic complications or difficulty in intubation of the airway, pregnancy, lactation and being under eighteen years old were considered exclusion causes for entry in the study.

Before the procedure the following parameters were recorded: reason for Gastrostomy indication, comorbidities, age, sex, weight and anesthetic risk according to ASA classification (Table I). All patients and/or their families were told the nature of the intervention and sedation, possible alternatives and potential risks. Each signed a specific document of informed consent.

Staff who participated in the explorations consisted of two medical gastroenterologists, a nurse and a nursing assistant. Doctors, one of them ran the endoscope and the other dealt with the abdominal side of the technique. The nurse was in charge of patient monitoring and administration of propofol at the orders of the doctors and with the help of the auxiliary to manipulate the endoscopic accessory equipment.

In all cases, antibiotic prophylaxis was provided and, via nasal cannula at a flow rate of four liters per minute, oxygen was administered to the patients throughout the procedure. Monitoring consisted of pulse-oximetry, continuous heart rate recording, and automatically at three minute intervals blood pressure measurement, starting immediately before beginning the procedure and continuing

Table I. Classification of anesthetic risk ASA

\begin{tabular}{l}
\hline Healthy patients \\
II $\quad \begin{array}{l}\text { Patients with mild disease that does not compromise its } \\
\text { activity (including children and elderly healthy subjects) }\end{array}$ \\
III $\quad \begin{array}{l}\text { Patients with moderate or severe disease that does not li- } \\
\text { mit its activity }\end{array}$ \\
IV Patients with severe disease that compromises their life \\
V $\quad$ Moribund patient \\
\hline
\end{tabular}

until the patient returned to his baseline, until after completion. The control of respiratory function was evaluated by observing the patient's respiratory movements. Propofol was administered via bolus, with an initial dose of $0.5 \mathrm{mg} / \mathrm{kg}$, and successive 10 to $20 \mathrm{mg}$ every $30-60$ seconds to reach the desired level of sedation, followed by further boluses of 10 to $20 \mathrm{mg}$, as required. Safety was controlled by the calibration of the alarms to oxygen saturation $<90 \%$, heart rate between 50 and 120 beats per minute and systolic blood pressure between 90 and $180 \mathrm{mmHg}$.

The quality of sedation was assessed by doctors, based on the immobility of the patient during the examination and whether or not restraint maneuvers were necessary. Complications were recorded as were the measures implemented to control them. Monitoring was continued until patients were able to score at or above 9 for a modified Aldrete scale (Table II), at which time they were discharged from the unit. The data analysis was performed using SPSS 11.

Table II. Aldrete scale (modified)

\begin{tabular}{|c|c|}
\hline Points & \\
\hline \multicolumn{2}{|l|}{ Activity } \\
\hline Move the 4 extremities voluntarily or to order & 2 \\
\hline Moves two extremities voluntarily or to order & 1 \\
\hline Unable to move limbs & 0 \\
\hline \multicolumn{2}{|l|}{ Breathing } \\
\hline Able to breathe deeply and cough freely & 2 \\
\hline Dyspnea or limited breathing & 1 \\
\hline Apnea & 0 \\
\hline \multicolumn{2}{|l|}{ Circulation } \\
\hline $\begin{array}{l}\text { TA difference less than or equal to } 20 \% \text { of } \\
\text { the pre-sedation level }\end{array}$ & 2 \\
\hline Unlike TA $20-50 \%$ pre-sedation level & 1 \\
\hline $\begin{array}{l}\text { TA difference greater than } 50 \% \text { of the pre-sedation } \\
\text { level }\end{array}$ & 0 \\
\hline \multicolumn{2}{|l|}{ Awareness } \\
\hline Wide awake & 2 \\
\hline Responds to call & 1 \\
\hline No answer & 0 \\
\hline \multicolumn{2}{|l|}{$\mathrm{O}_{2}$ Saturation } \\
\hline Superior to $92 \%$ in room air & 2 \\
\hline Need to keep $\mathrm{O}_{2}$ Sat > 90\%. & 1 \\
\hline Less than $90 \%$ with $\mathrm{O}_{2}$ & 0 \\
\hline
\end{tabular}

\section{RESULTS}

Were included in the study 47 patients, whose characteristics were as follows (Table III):

-Sex: 26 men and 21 women. Age: the average age was 82 years. 29 patients were over 80 years of age, and only two were under 70 . 
Table III. Patient characteristics

\begin{tabular}{ll}
\hline Total & 47 \\
Sex & Men 26, women 21 \\
Median age & 82 years (39-97) \\
Average weight & $66 \mathrm{~kg}(45-85)$ \\
PEG indication & Dementia 24, AVCA 18, Parkinson 3, ELA 2 \\
ASA grade & III: 41, IV: 6 \\
\hline
\end{tabular}

-Anesthetic risk: 87\% (41 patients) were ASA III. The rest were ASA IV (Table III).

- The average weight was $66 \mathrm{~kg}$ (45-85).

-Indication for gastrostomy: dementia 24, AVCA 18, Parkinson 3, ELA 2.

-Dose of propofol: the average dose was $51 \mathrm{mg}$, ranging between 20 and $91 \mathrm{mg}$.

-Complications (Table IV): arterial desaturation (Sa $\mathrm{O}_{2}$ below 90\%): 8 episodes in 8 patients (17\%). Hypotension (systolic BP less than $90 \mathrm{mmHg}$ ): 2 episodes in 2 patients $(4.2 \%)$. Bradycardia ( $\mathrm{P}$ less than 50 beats per minute): no episode. All complications quickly reversed after applying simple maneuvers, such as increased oxygen flow, traction of the mandible or rapid infusion of saline. There were no serious complications and no need of life support. 20).

-Time spent performing art: 8 minutes (range 6 to

-Postprocedure time until discharge from the Unit: 11 minutes (range 8 to 25 ).

-Technical success: $100 \%$.

Table IV. Propofol dose and complications

\begin{tabular}{ll}
\hline Propofol dose & $51 \mathrm{mg} \mathrm{(20-91)}$ \\
Desaturation & $8(17 \%)$ \\
Hypotension & $2(4.2 \%)$ \\
Bradycardia & 0 \\
\hline
\end{tabular}

\section{DISCUSSION}

Propofol (2-6 diisopropilphenol) is an ultra fast-acting drug with hypnotic and an amnesic and slightly analgesic effect, which has a short half life, allowing rapid recovery of the patient. These properties make it a very useful agent for sedation in endoscopic procedures. However, their therapeutic window is narrow, forcing a fit of the dose to avoid causing deterioration of cardiorespiratory function. For this reason and because of not having an antidote, the non- anesthesiologist use of propofol by doctors has raised controversy. However, in recent years nu- merous studies have been published and they have demonstrated an acceptable safety and efficacy when propofol sedation during endoscopic procedures was controlled directly by endoscopists or by properly trained nurses, although most of these studies were carried out during basic endoscopic procedures, and in lower anesthetic risk patients, with few studies relating to advanced endoscopy or in patients with a higher anesthetic risk (16-22).

Percutaneous endoscopic gastrostomy is a technique which has increased in demand, with a technical complexity that ranges from advanced endoscopic procedures and is generally applicable to elderly, debilitated and patients who are carriers of comorbidities. For these reasons, and because of the lack of written references, we carried out a prospective study to evaluate safety and efficacy of propofol sedation controlled by endoscopists themselves during this procedure.

In assessing the results of the study, we must underline that the population tested was in full high anesthetic risk groups, ASA III and IV, with an average age over 80 . On the other hand it is important to stress the low weight of many of them (66 kg on average) and the short time in which the procedure were completed ( 8 minutes on average). All these factors explain the very low dose of propofol that were applied, $51 \mathrm{mg}$ of average, much lower than those reported during examinations such as colonoscopies, ERCP or EUS (23).

There were complications in $21 \%$ of cases, all mild and easily reversible. There were no serious complications. In $17 \%$ of patients desaturations were observed, which was somewhat higher than that evidenced in other works, as in that of Riphaus (16), which were observed in $11 \%$, probably in relation to the characteristics mentioned above for our patients. Importantly, because it was one of the objectives of the study, exploration tolerance by the patients was excellent, without it being necessary to use physical restraint maneuvers. Technical success was achieved in all cases and exploration was not discontinued in any of them before completion.

The study also highlights the short period of stay in the Endoscopy Unit until discharge after completion of exploration. Patients were monitored until they regained their previous baseline, confirmed by a modified Aldrete scale. The average 11 minutes of our patients is again far from the usual time needed to discharge patients sedated with benzodiazepines and opiates $(24,25)$.

As for the measures taken for monitoring, pulseoximetry and control of blood pressure and heart rate were recorded. A capnograph was not used, controlling respiratory function by visual observation of respiratory movements of the patients. The main clinical guidelines on sedation in gastrointestinal endoscopy stress the absence of studies demonstrating the need for capnography in these cases, although they recommend its use for various other reasons such as the room being dark or because the patient's position prevents the observation of the res- 
piratory excursions or the color of the patient $(5,8)$. In our case, the patients were supine and the endoscopy room was well lit during the entire procedure, so we had no difficulty at all times to monitor the respiratory status of patients.

In conclusion, the results of this study seem to support that the use of propofol by non-anesthesiologists is a valid option, safe and reliable while performing advanced endoscopic procedures in anesthetic risk population. In any case, our group is calling for joint development, between gastroenterologists and anesthesiologists, of protocols in endoscopic sedation and monitoring, as well as conducting training and retraining, as a way to get the best cost/benefit possible in the care to our patients.

\section{REFERENCES}

1. Vargo JJ. Zuccaro G Jr, Dumot JA, Shay SS, Conwell DL, Morrow JB. Gastroenterologist administered propofol for therapeutic upper endoscopy with graphic assessment of respiratory activity: a case series. Gastrointest Endosc 2000; 52(2): 250- 3.

2. Vargo JJ, Zuccaro G Jr, Dumot JA, Shermock KM, Morrow JB, Conwell DL, et al. Gastroenterologist-administered propofol versus meperidine and midazolam for advanced upper endoscopy: A prospective, randomized trial. Gastroenterology 2002; 123: 8-16.

3. Koshy G. Nair S, Norkus EP, Hertan HI, Pitchumoni CS. Propofol versus midazolam and meperidine for conscious sedation in GI endoscopy. Am J Gastroenterol 2000; 95(6): 1476-9.

4. A report by the American Society of Anesthesiologists Task Force on sedation and analgesia by non-anesthesiologists. Practice guide lines in sedation and analgesia by non anesthesiologists. Anesthesiology 1996; 84: 459-71.

5. American Society for Gastrointestinal Endoscopy. Guidelines for training in patient monitoring and sedation and analgesia. Gastrointest Endosc 1998; 48: 669-71.

6. American Society for Gastrointestinal Endosocpy. Guidelines for the use of deep sedation and anesthesia for GI endoscopy. Gastrointest Endosc 2002; 56: 613-7.

7. Cohen BL, Delegge MH, Aisenberg J, Brill JV, Inadomi JM, Kochman ML, et al. AGA Institute review of endoscopic sedation. Gastroenterology 2007; 133: 675-701.

8. Communication from the ASGE Standards of Practice Committee. Sedation an anesthesia in GI endoscopy. Gastrointest Endosc 2008; 68(5): 815-26.

9. López Rosés L and subcomité de protocolos of the Spanish Society of Gastrointestinal Endoscopy (SEED). Sedation/Analgesia guide lines for endoscopy. Rev Esp Enferm Dig 2006; 98: 685-92.

10. Simón MA, Bordas JM, Campo R, González-Huix F, Igea F, Monés J. Documento de consenso de la Asociación Española de Gastroenterología sobre sedoanalgesia en Endoscopia Digestiva. Gastroen- terol Hepatol 2006; 29: 131-49.

11. American Society for Gastrointestinal Endoscopy. Training guideline for use of propofol in gastrointestinal endoscopy. Gastrointest Endosc 2004; 60: 167-72.

12. Bye MF, Chiba N, Singh H, Sadowski DC for the Clinical Affairs of the Canadian Association of Gastroenterology. Propofol use for sedation during endoscopy in adults: a Canadian Association of Gastroenterology position statement. Can J Gastroenterol 2008; 22: 4579.

13. Rex DK. Overley C, Kinser K, Coates M, Lee A, Goodwine BW, et al. Safety of propofol administered by registered nurses with gastroenterologist supervision in 2000 endoscopic cases. Am J Gastroenterol 2002; 97: 1159-63.

14. Heuss LT, Schnieper P, Drewe J, Pflimlin E, Beglinger C. Risk stratification and safe administration of propofol by registered nurses supervised by the gastroenterologist: a prospective observational study of more than 2000 cases. Gastrointest Endosc 2003; 57: 664-71.

15. Sipe BW, Rex DK, Latinovich D, Overley C, Kinser K, Bratcher L, et al. Propofol versus midazolam/meperidine for outpatient colonoscopy: administration by nurses supervised by endoscopists. Gastrointest Endosc 2002; 55: 815-24.

16. Riphaus A, Stergiou N, Wehrmann T. Sedation with propofol for routine ERCP in high risk octogenarians. A randomized, controlled study. Am J Gatroenterology 2005: 100: 1957-63.

17. Jung M, Hofmann C, Kiesslich R, Brackertz A. Improved sedation in diagnosis and therapeutic ERCP: propofol is an alternative to midazolam. Endoscopy 2000; 32: 233-8.

18. Repiso A, Gómez-Rodríguez R, García-Vela A, Pérez-Grueso MJ, Martín R, Romero M, et al. Estudio por ecoendoscopia de la vía biliar extrahepática en pacientes con pancreatitis aguda. Rev Esp Enferm Dig 2008; 100: 337-42.

19. Espinel J, Pinedo E. Dilatación de la papilla de Vater con balón de gran diámetro para la extracción de coledocolitiasis. Rev Esp Enferm Dig 2008; 100: 632-6.

20. Espinel J, Pinedo E, Rascarachi G. Endoscopic mucosal resection with a multiband ligador for the treatment of Barrett's high-grade dysplasia and early gastric cancer. Rev Esp Enferm Dig 2009; 101: 403-7.

21. Heuss LT, Schnieper P, Drewe J, Pflimlin E, Beglinger C. Conscious sedation with propofol in elderly patients: a prospective evaluation. Aliment Pharmacol Ther 2003; 17: 1493-501.

22. Heuss LT, Schnieper P, Drewe J, Pflimlin E, Beglinger C. Safety of propofol for conscious sedation during endoscopic procedures in high risk patients. A prospective, controlled study. Am J Gastroenterol 2003; 98: 1494-501.

23. Heuss LT, Peter S. Propofol use by gastroenterologists. The European experience. Gastrointest Endosc Clin N Am 2008; 18: 72738.

24. Sipe BW, Rex DK, Latinovich D, Overley C, Kinser K, Bratcher L, et al. Propofol versus midazolam/ meperidine for outpatient colonoscopy: administration by nurses supervised by endoscopists. Gastrointest Endosc 2002; 55: 815-25.

25. Ulmer BJ, Hansen JJ, Overley CA, Symms MR, Chadalawada V, Liangpunsakul S, et al. Propofol versus midazolam/fentanyl for outpatient colonoscopy: administration by nurses supervised by endoscopists. Clin Gastroenterol Hepatol 2003; 1: 425-43. 


\title{
Sedación con propofol controlada por endoscopista durante la realización de gastrostomía percutánea endoscópica
}

\author{
C. García Suárez, L. López Rosés, P. Olivencia, A. Lancho, A. González Ramírez, E. Santos, \\ D. Carral, E. Castro y S. Ávila
}

Servicio de Aparato Digestivo. Hospital Xeral-Calde. Lugo

\section{RESUMEN}

Introducción: el propofol es un hipnótico usado cada vez con más frecuencia para la sedación durante procedimientos endoscópicos. La mayor parte de los trabajos publicados en relación con su empleo por personal no anestesista se refiere a exploraciones de endoscopia básica, siendo escasas las referencias a su empleo en endoscopia avanzada.

Objetivo: valorar la eficacia y la seguridad de la sedación mediante propofol administrado por endoscopistas, durante la realización de gastrostomía endoscópica percutánea, técnica avanzada y generalmente aplicada sobre pacientes de riesgo anestésico alto.

Material y métodos: estudio prospectivo de una serie de gastrostomías endoscópicas realizadas consecutivamente en nuestro servicio; las sedaciones se llevaron a cabo exclusivamente con propofol. El personal presente en la sala consistió en dos médicos gastroenterólogos, una enfermera y una auxiliar de enfermería. El propofol se administró en bolos, ajustando las dosis al peso de los pacientes. Se monitorizaron la saturación arterial de oxígeno, la frecuencia cardiaca y la tensión arterial. La actividad respiratoria se controló de forma visual mediante la observación de las excursiones respiratorias de los enfermos.

Resultados: se incluyeron 47 pacientes, con una edad media de 82 años. El $87 \%$ fueron ASA III y el resto ASA IV. La dosis media de propofol fue de $51 \mathrm{mg}$. Como complicaciones se registraron 8 casos de desaturación y dos de hipotensión, todas leves y rápidamente reversibles. Todos los procedimientos se llevaron a cabo satisfactoriamente, en un tiempo medio de 8 minutos.

Conclusión: la sedación mediante propofol llevada a cabo por personal entrenado no anestesista parece mostrarse como un método seguro y eficaz durante la realización de gastrostomía percutánea endoscópica.

Palabras clave: Propofol. Gastrostomía percutánea endoscópica. Sedación por no anestesistas.

\section{INTRODUCCIÓN}

La realización de procedimientos endoscópicos bajo sedación y analgesia se ha venido convirtiendo en algo cada vez más frecuente en la práctica clínica, debido por un lado a la mayor complejidad y duración de algunos de ellos y por otro a la exigencia por parte de los pacientes de no ser sometidos a exploraciones molestas ni dolorosas. Habitualmente esta sedación ha sido superficial y se ha llevado a cabo mediante el empleo de benzodiazepinas, asociadas o no opiáceos; sin embargo desde hace algunos años, y a la vista de los buenos resultados publicados en la literatura médica, es cada vez mayor el número de endoscopistas que ha comenzado a utilizar fármacos hipnóticos más potentes, concretamente propofol, al tiempo que practicaban niveles de sedación más profundos (1-3). Ello ha generado una gran polémica en torno a quién debería encargarse de la sedación y monitorización de los pacientes y si el personal sanitario no anestesiólogo está o no capacitado para emplear propofol, debido principalmente al estrecho margen terapéutico de este fármaco. El debate ha sido zanjado parcialmente tras la aparición de varias guías de manejo clínico publicadas por diferentes sociedades científicas, que establecen las condiciones que debe cumplir el personal dedicado a la sedación tanto superficial como profunda y las situaciones en las que la misma debe ser llevada a cabo por anestesiólogos (4-12). No obstante, a pesar de la gran cantidad de trabajos publicados sobre sedación en endoscopia digestiva controlada por médicos no anestesistas o enfermeras entrenadas (1315), apenas existen artículos que se refieran a su empleo durante procedimientos de endoscopia avanzada $(2,16$ 20). Es por ello que nos propusimos valorar de forma prospectiva la seguridad y calidad de la sedación con propofol controlada por endoscopista durante la práctica de gastrostomía percutánea endoscópica, procedimiento de cierta complejidad técnica y que se lleva a cabo habitualmente en pacientes de riesgo anestésico elevado, factores ambos que sitúan el procedimiento en la proximidad del límite generalmente aceptado para considerar necesaria la presencia de un médico anestesista.

\section{MATERIAL Y MÉTODOS}

Se llevó a cabo un estudio prospectivo descriptivo que incluyó la totalidad de los pacientes remitidos a la Unidad de Endoscopia de nuestro Servicio para la colocación de una sonda de gastrostomía, desde marzo a octubre de 2008. 
El procedimiento se realizó en todos los casos empleando la técnica por tracción y la sedación empleada fue exclusivamente a base de propofol.

En el diseño del estudio se consideraron causas de exclusión del mismo la alergia al propofol, al huevo o a la soja, las enfermedades pulmonares o cardiacas descompensadas, los antecedentes de complicaciones anestésicas o de dificultad para la intubación de la vía aérea, el embarazo, la lactancia y la edad inferior a dieciocho años.

Antes de comenzar el procedimiento se registraron los siguientes parámetros: motivo de la indicación de gastrostomía, comorbilidades, edad, sexo, peso y riesgo anestésico según la clasificación ASA (Tabla I). A todos los pacientes y/o a sus familiares se les explicó las características de la intervención y de la sedación, las posibles alternativas y los posibles riesgos. Todos ellos firmaron un documento específico de consentimiento informado.

Tabla I. Clasificación ASA de riesgo anestésico

\begin{tabular}{l}
\hline Paciente sano \\
II $\quad \begin{array}{l}\text { Paciente con enfermedad leve que no compromete su acti- } \\
\text { vidad (incluye niños y ancianos sanos) }\end{array}$ \\
III Paciente con enfermedad moderada o grave que no limita \\
su actividad \\
IV Paciente con enfermedad grave que compromete su vida \\
V Paciente moribundo \\
\hline
\end{tabular}

El personal que participó en las exploraciones consistió en dos médicos gastroenterólogos, una enfermera y una auxiliar de enfermería. De los médicos, uno de ellos manejaba el endoscopio y el otro se ocupaba de la vertiente abdominal de la técnica. La enfermera era la encargada de la monitorización del paciente y de la administración del propofol, bajo las órdenes de los médicos y la auxiliar ayudaba en la manipulación del material endoscópico accesorio.

En todos los casos se realizó profilaxis antibiótica y durante todo el procedimiento se administraba a los pacientes oxígeno mediante gafas nasales a un flujo de cuatro litros por minuto.

La monitorización consistió en pulsioximetría y registro de la frecuencia cardiaca continuos, y toma automática de la tensión arterial cada tres minutos, comenzando antes de iniciar el procedimiento y continuando hasta que el paciente volvía a su situación basal, una vez concluido el mismo. El control de la función respiratoria se llevó cabo mediante la observación de los movimientos respiratorios del paciente.

El propofol se administró mediante bolos, con una dosis inicial de $0,5 \mathrm{mg} / \mathrm{kg}$, y sucesivas de $10-20 \mathrm{mg}$ cada 30-60 segundos hasta alcanzar el nivel de sedación deseado, y posteriormente mediante nuevos bolos de 10-20 $\mathrm{mg}$, según las necesidades.
La seguridad se controló mediante la calibración de las alarmas a saturación de oxígeno de $<90 \%$, frecuencia cardiaca entre 50 y 120 latidos por minuto y tensión arterial sistólica entre 90 y $180 \mathrm{mmHg}$.

La calidad de la sedación se valoró por los médicos, en base a la inmovilidad del paciente durante la exploración y a la necesidad o no de practicar maniobras de restricción física del mismo. Se registraron las complicaciones surgidas así como las medidas aplicadas para el control de las mismas.

Tras el procedimiento se mantuvo la monitorización hasta que los pacientes lograban una puntuación igual o superior a 9 de una escala de Aldrete modificada (Tabla II), momento en el que eran dados de alta de la Unidad.

El análisis de los datos se llevó a cabo mediante el programa SPSS 11.

Tabla II. Escala de Aldrete (modificada)

\begin{tabular}{ll}
\hline \multicolumn{1}{c}{ Puntos } & \\
\hline Actividad & 2 \\
Mueve las 4 extremidades voluntariamente o ante órdenes & 1 \\
Mueve dos extremidades voluntariamente o ante órdenes & 0 \\
Incapaz de mover extremidades & \\
Respiración & 2 \\
Capaz de respirar profundamente y toser libremente & 1 \\
Disnea o limitación de la respiración & 0 \\
Apnea & \\
Circulación & 2 \\
Diferencia de TA menor o igual 20\% del nivel presedación & 1 \\
Diferencia de TA 20-50\% del nivel presedación & 0 \\
Diferencia de TA superior a 50\% del nivel presedación & \\
Conciencia & 2 \\
Completamente despierto & 1 \\
Responde a llamada & \\
No responde & \\
Saturación $\mathrm{O}_{2}$ & \\
Superior a 92\% con aire ambiente & \\
Necesita $\mathrm{O}_{2}$ para mantener Sat > 90\% & \\
Menor de 90\% con $\mathrm{O}_{2}$ & 2 \\
\hline
\end{tabular}

\section{RESULTADOS}

Se incluyeron en el estudio 47 pacientes, cuyas características fueron las siguientes (Tabla III):

-Sexo: 26 hombres y 21 mujeres. Edad: la mediana de edad fue de 82 años. Veintinueve pacientes superaban los 80 años de edad, y solamente dos eran menores de 70 . -Riesgo anestésico: el 87\% ( 41 pacientes ) eran ASA III. El resto, ASA IV (Tabla III).

-El peso medio fue de $66 \mathrm{~kg}$ (45-85).

-Indicación de la gastrostomía: demencia 24, AVCA 18, Parkinson 3, ELA 2.

-Dosis de propofol: la dosis media fue de $51 \mathrm{mg}$, con un rango entre 20 y $91 \mathrm{mg}$. 
Tabla III. Características de los pacientes

\begin{tabular}{ll}
\hline$N^{\circ}$ total & 47 \\
Sexo & Hombres 26, mujeres 21 \\
Edad media & 82 años (39-97) \\
Peso medio & $66 \mathrm{~kg}(45-85)$ \\
Indicación & Demencia 24, AVCA 18, Parkinson 3, ELA 2 \\
Grado ASA & III: 41, IV: 6 \\
\hline
\end{tabular}

-Complicaciones (Tabla IV): desaturaciones arteriales $\left(\mathrm{Sa} \mathrm{O}_{2}\right.$ menor de 90\%): 8 episodios en 8 pacientes (17\%). Hipotensión (TA sistólica menor de $90 \mathrm{mmHg}$ ): 2 episodios en 2 pacientes $(4,2 \%)$. Bradicardia (P menor de 50 latidos por minuto): ningún episodio. Todas las complicaciones revirtieron con rapidez tras aplicar maniobras sencillas, tales como aumento del flujo de oxígeno, tracción de la mandíbula o infusión rápida de suero salino. No se registraron complicaciones graves ni se precisaron medidas de soporte vital.

-Tiempo empleado en la realización de la técnica: 8 minutos (rango de 6 a 20).

- Tiempo postprocedimiento hasta el alta de la Unidad: 11 minutos (rango de 8 a 25).

-Éxito técnico: $100 \%$.

Tabla IV. Dosis de propofol y complicaciones

\begin{tabular}{ll}
\hline Dosis propofol & $51 \mathrm{mg}(20-91)$ \\
Desaturaciones & $8(17 \%)$ \\
Hipotensión & $2(4,2 \%)$ \\
Bradicardia & 0 \\
\hline
\end{tabular}

\section{DISCUSIÓN}

El propofol (2-6 diisopropilfenol) es un fármaco de acción ultra rápida con efecto hipnótico y amnésico y levemente analgésico, que posee una vida media corta, lo cual permite una recuperación rápida del paciente; estas propiedades le convierten en un agente muy útil para la sedación en procedimientos endoscópicos. Sin embargo su ventana terapéutica es estrecha, obligando a un ajuste perfecto de las dosis para evitar provocar deterioro de la función cardiorrespiratoria; por dicho motivo y por el hecho de no disponer de un antídoto, el empleo de propofol por médicos no anestesistas ha suscitado controversia. No obstante, en los últimos años han sido muy numerosos los estudios publicados que demostraban una seguridad y efectividad aceptables cuando la sedación con propofol durante procedimientos endoscópicos era controlada directamente por endoscopistas o por enfer- meras debidamente entrenadas, si bien es cierto que la mayoría de dichos estudios se llevaron cabo durante procedimientos de endoscopia básica y en pacientes de riesgo anestésico bajo, siendo escasos los trabajos referidos a endoscopia avanzada o en pacientes con riesgo anestésico superior (16-22).

La gastrostomía percutánea endoscópica es una técnica cada vez más demandada, con una complejidad técnica que la sitúa entre los procedimientos de endoscopia avanzada y que se aplica a pacientes por lo general debilitados, de edad avanzada y portadores de comorbilidades. Por estas razones y por no existir referencias en la literatura, decidimos realizar un estudio prospectivo que valorara la seguridad y eficacia de la sedación con propofol controlada por los propios endoscopistas durante este procedimiento.

Al valorar los resultados del estudio se observa que la población analizada correspondía en su totalidad a grupos de riesgo anestésico alto, ASA III y IV, siendo además su edad media superior a los 80 años. Por otro lado es importante señalar el peso bajo de muchos de ellos (66 $\mathrm{kg}$ de media) y el tiempo corto en el que se completaron las exploraciones ( 8 minutos de promedio). Todos estos factores explican las dosis de propofol tan bajas que fueron aplicadas, $51 \mathrm{mg}$ de media, muy inferiores a las reportadas durante exploraciones tales como colonoscopias, CPRE o ecoendoscopias (23).

Se registraron complicaciones en el $21 \%$ de los casos, todas ellas leves y fácilmente reversibles. No se registraron complicaciones graves. En el 17\% de los pacientes se produjeron desaturaciones, cifra algo superior a la evidenciada en otros trabajos, como el de Riphaus (16), en el que se observaron en el 11\%, probablemente en relación con las características ya mencionadas de nuestros enfermos. Es importante señalar, pues era uno de los objetivos del estudio, que la tolerancia a la exploración por parte de los pacientes fue excelente sin que fuera preciso recurrir a maniobras de restricción física, y que se logró el éxito técnico en todos los casos, no debiendo suspenderse la exploración antes de su finalización en ninguno de ellos. También en el estudio se pone en evidencia el corto periodo de permanencia en la Unidad de Endoscopia hasta el alta de la misma una vez concluido el procedimiento endoscópico. Los pacientes fueron controlados hasta que recuperaron su situación basal previa, confirmada mediante una escala de Aldrete modificada. Los 11 minutos de media de nuestros enfermos quedan de nuevo muy lejos del tiempo habitualmente necesario para poder dar de alta a los pacientes sedados con benzodiazepinas y opiáceos $(24,25)$.

En cuanto a las medidas de monitorización, se emplearon la pulsioximetría, y el control de la tensión arterial y de la frecuencia cardiaca. No se utilizó un capnógrafo, controlándose la función respiratoria mediante la observación visual de los movimientos respiratorios de los pacientes. Las principales guías clínicas sobre sedación en 
endoscopia digestiva resaltan la ausencia de estudios que demuestren la necesidad del registro capnográfico en estos casos, aunque recomiendan su empleo cuando por diversas causas, como el oscurecimiento de la sala o la posición del paciente, no puedan observarse las excursiones respiratorias o la coloración del enfermo $(5,8)$. En nuestro caso, la sala permanecía con luz y el paciente en posición de decúbito supino durante la totalidad del procedimiento, por lo que no tuvimos ninguna dificultad para controlar en todo momento la situación respiratoria de los enfermos.
En conclusión, los resultados de este trabajo parecen apoyar que el empleo de propofol por personal entrenado no anestesista, es una opción válida, segura y fiable, durante la realización de procedimientos de endoscopia avanzada y en población de riesgo anestésico. En cualquier caso, nuestro grupo aboga por la elaboración conjunta entre gastroenterólogos y anestesistas, de protocolos de sedación y monitorización en endoscopia, así como por la realización de cursos de formación y reciclaje, como fórmula para conseguir la mejor relación coste/beneficio posible en la asistencia a nuestros pacientes. 